\title{
RANCANG BANGUN ALAT PENGERING SISTEM ISOLATOR BERLAPIS PAPAN BATU KERIKIL SEBAGAI PENYIMPAN PANAS
}

\author{
Juandi M1, Usman Malik, ${ }^{1, *}$, Ismawan ${ }^{2, *}$ \\ ${ }^{1}$ Dosen Fisika Bidang Kebumian dan Lingkungan \\ ${ }^{2}$ Mahasiswa Program S1 Fisika \\ Jurusan Fisika \\ Fakultas Matematika dan Ilmu Pengetahuan Alam, \\ Universitas Riau Kampus Bina Widya \\ J1. HR Sobrantas KM 12,5, Pekanbaru, 28293, Indonesia \\ *Email korespondensi: anakbambangsuardi@gmail.com; \\ usman.malik@lecturer.unri.ac.id
}

\begin{abstract}
Research on the design of a dryer with an insylation system made of pebble and board for heat storage. This research as conducted using experimental method by making a dryer using biomass energy sources. The objectives of the study were to measurins the heat rate lost from each side of the dryer, the heat energy generated from the combustion of the coconut shell the moisture content of drying wet clothing, the efficiency of the drying time The results showed the design of a dryer with an insylation system made of pebble and board for heat storage works well. The temperature inside the room is ranges from $\left(40-68^{\circ} \mathrm{C}\right)$. The total rate of heat energy lost in the 10 th minute is $6,527.54 \mathrm{~J} / \mathrm{s}$ and continued to decrease to 60 th minute by $3263.77 \mathrm{~J} / \mathrm{s}$. The heat energy rate resulting from the combustion of coconut shells at 10th mins is $10520 \mathrm{~J} / \mathrm{s}$ and continued to decrease to 60th minute by $1753.33 \mathrm{~J} / \mathrm{s}$. Reduced moisture content of wet clothes reached $2.439 \%$ at 60 minutes. Efficiency of drying time reaches $85.7 \%$. The efficiency of the average biomass energy source is $90 \%$.
\end{abstract}

Keywords: Dryer, heat storage,biomass.

\begin{abstract}
ABSTRAK
Penelitian tentang perancangan alat pengering dengan sistem isolator yang terbuat dari kerikil dan papan untuk penyimpanan panas. Penelitian ini dilakukan dengan menggunakan metode eksperimen dengan membuat pengering dengan menggunakan sumber energi biomassa. Tujuan penelitian ini adalah untuk mengukur tingkat panas yang hilang dari masing-masing sisi pengering, energi panas yang dihasilkan dari pembakaran tempurung kelapa dengan kadar air pakaian basah hasil pengeringan, efisiensi waktu pengeringan. Hasil menunjukkan disain Pengering dengan sistem isolator yang terbuat dari kerikil dan papan untuk penyimpanan panas bekerja secara baik. Suhu di dalam ruangan berkisar antara $\left(40-68^{\circ} \mathrm{C}\right)$. Tingkat total energi panas yang hilang pada menit ke-10 adalah 6.527,54 J/s dan terus menurun hingga 60 menit sebesar $3263.77 \mathrm{~J} / \mathrm{s}$. Tingkat energi panas yang dihasilkan dari pembakaran tempurung kelapa pada menit ke 10 adalah $10520 \mathrm{~J} / \mathrm{s}$ dan terus menurun sampai 60 menit 1753,33 J/s. Mengurangi kadar air pakaian basah mencapai 2,439\% pada 60 menit. Efisiensi waktu pengeringan mencapai $85,7 \%$. Efisiensi sumber energi biomassa rata-rata adalah $90 \%$.
\end{abstract}

Kata kunci: Pengering, penyimpanan panas, biomassa.

\section{PENDAHULUAN}

Alat pengering yang ramah lingkungan menjadi tren saat ini. Salah satunya adalah pengering berbasis biomassa. Pengering jenis ini merupakan inovasi dari pengering tradisional yang telah ada dengan desain yang lebih efisein. Pengering berbasis biomassa telah difungsikan untuk beragam keperluan, seperti pengering karet [1], rengginang[2], padi [3], dan pati sagu[4]. Adapun biomassa yang digunakan diantaranya adalah tempurung kelapa [5], pelepah sawit [2], dan cangkang kakao[6]. Karakteristik fisis berbagai jenis briket biomassa, seperti massa jenis dalam bentuk briket dan kalor yang dilepas briket biomassa telah dijelaskan dengan baik oleh referensi [8].

Pengeringan paling praktis adalah menggunakan sinar matahari secara langsung. Namun, keberadaan sinar matahari sangat 
bergantung pada waktu dan cuaca harian [9]. Bila cuaca mendung atau malam hari, proses pengeringan akan berlangsung lebih lama. Sehingga penggunaan sinar matahari dirasa kurang efisien dan dikembangkan jenis pengering berbasis biomassa. Keuntungan penggunaan pengering berbasis biomassa adalah ramah lingkungan, berbiaya murah dan lebih efesien daripada pengeringan langsung dengan sinar matahari. Bila dioperasikan pada ruang berpenutup, pengering biomassa dapat digunakan sesuai kebutuhan tanpa memperhatikan cuaca hujan atau malam hari [10].

Penelitian ini merancang dan mengevaluasi alat pengering berbasis biomassa dengan kerikil sebagai media penyimpan panas. Pengering ini diaplikasikan untuk mengeringkan pakaian basah setelah dicuci. Pemilihan sebagai pengering pakaian didasarkan karena pakaian merupakan kebutuhan dasar manusia [11]. Pakaian harus senantiasa dibersihkan melalui proses pencucian dan selanjutnya harus dikeringkan untuk dapat digunakan kembali. Dengan menggunakan pengering biomassa, pakaian yang dikeringkan dapat terjaga kebersihannya karena berada diruangan tertutup [12]. Selain itu diharapkan proses pengeringannya menjadi lebih cepat dan terkendali.

\section{METODOLOGI PENELITIAN}

\section{Alat Pengering Energi Biomassa}

Alat pengering ini dibuat berbentuk persegi panjang dengan panjang $90 \mathrm{~cm}$, lebar $45 \mathrm{~cm}$, dan tinggi $170 \mathrm{~cm}$. Alat pengering dibuat berdindingkan tripleks dan pada bagian dalam dilapisi seng dengan ketebalan $0.7 \mathrm{~mm}$, bagian permukaaan seng diberi cat berwarna hitam. Setelah ukuran kayu sudah sesuai dengan ukuran yang dikehendaki dan hubungkan masing-masing sisi kayu dengan sisi kayu yang lainnya menggunakan paku.

\section{Ruang Pengering}

Ruangan pengering diisi dengan 1 penyangga atau 1 tempat penggantung pakaian, $15 \mathrm{~cm}$ jarak dari tempat penggantung pakaian keatap ruang pengering,dan $100 \mathrm{~cm}$ dari ruang energi biomassa. Pada dasar ruangan pengering diisi dengan drum yang berukuran $50 \mathrm{~cm}$ dan diameter $40 \mathrm{~cm}$. Drum ini berfungsi untuk mengolah limbah tempurung kelapa menjadi energi biomassa yang menimbulkan panas yang dapat mengeringkan pakaian basah. Pada bagian atas ruangan pengeringini diberi cerobong untuk jalan udara keluar dari dalam ruangan pengering.

\section{Prosedur Penelitian}

Prosedur penelitian yang dilakukan adalah:

1. Perancangan struktur bangun alat pengering Energi Biomassa.

2. Persiapan alat dan bahan penelitian yang meliputi:

a) alat pengering energi biomassa dari limbah tempurung kelapa dibuat dengan kerangka kayu dan berdindingkan seng tebalnya 0,7 $\mathrm{mm}$, tepat ditengah dinding berlapis triplek yang tebalnya $8 \mathrm{~mm}$, dan pada bagian dalamnya dilapisi seng lagi dengan ketebalan 0,7 mm, bagian permukaaan seng diberi cat berwarna hitam, alat pengering energy biomassa ini dilengkapi dengan rak penggantung baju yang terbuat dari kawat besi, cerobong yang terbuat dari plat seng dan ruang energi biomassa yang berasal dari drum.

b) pakaian yang kotor dibersihkan, kemudian ditempatkan pada penggantung baju pengering untuk dikeringkan.

3. Pengambilan data

Pengukuran parameter suhu dilakukan tiap 10 menit menggunakan termometer merkuri yang meliputi pengukuran suhu lingkungan sekitar, suhu dalam ruang pengering, suhu pada permukaan drum, suhu disetiap sisi dinding alat pengering. Massa pakaian basah pada setiap rak ditimbang dengan dengan timbangan dan pengaturan suhu dalam ruang pengering antara $57-68^{\circ} \mathrm{C}$. 


\section{HASIL DAN PEMBAHASAN}

Analisa Suhu Bagian Dalam dan Luar Alat Pengering

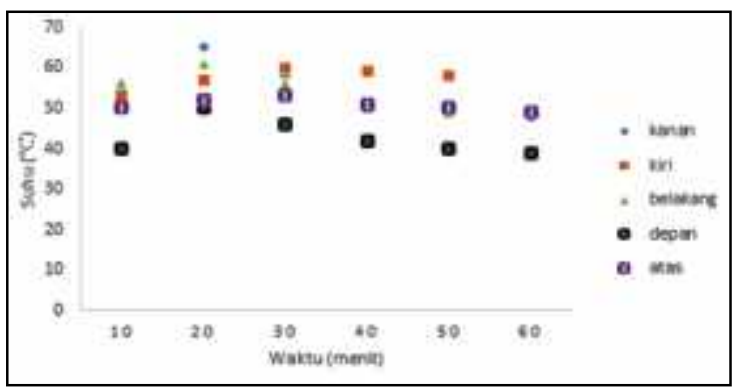

Gambar 1. Suhu di dalam alat pengering terhadap waktu

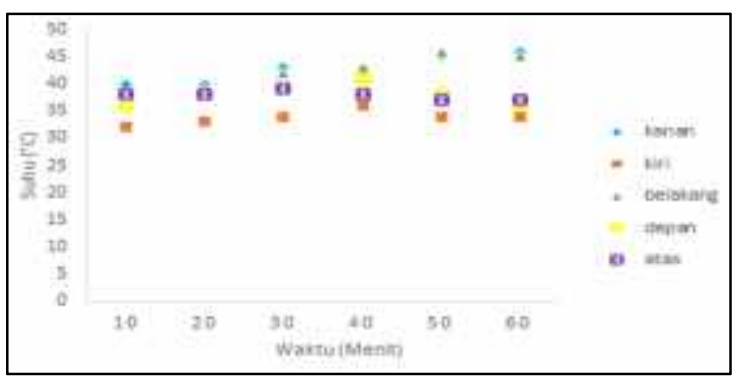

Gambar 2. Suhu di luar alat pengering terhadap waktu

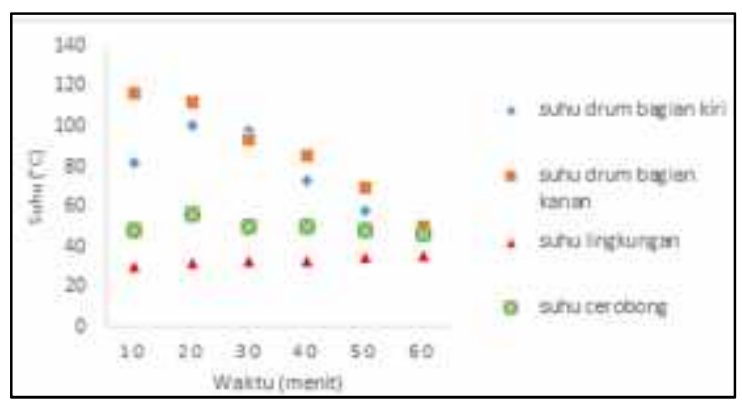

Gambar 3. Suhu di dalam drum dan cerobong.

Data hasil pengamatan Suhu pada alat Pengering terhadap waktu selama 60 menit dengan interval waktu pengamatan 10 menit. Pola penyebaran suhu di dalam ruang pengering dapat dilihat pada gambar 1. Bagian dalam ruang pengering memiliki fluktuasi suhu yang tidak merata. Grafik 1 memperlihatkan bahwa terdapat 3 bagian suhu yaitu tinggi, sedang dan rendah, dimana suhu tinggi terjadi pada sisi kanan dan sisi kiri yang disebabkan oleh adanya kontak langsung dengan sumber panas, sedangkan suhu sedang terjadi pada sisi belakang karena sisi belakang terkena radiasi panas dan terkena paparan dari sinar mataharisehingga suhu nya cenderung lebih kecil dari suhu sisi kanan dan sisi kiri. Suhu terendah terjadi pada sisi depan dan sisi atas karena tidak terjadi kontak langsung dengan sisi tersebut.

Gambar 2 menunjukkan distribusi suhu diluar alat pengering dimana suhu tersebut cenderung konstan dan mendekati suhu lingkungan karena dipengaruhi oleh suhu udara luar. Gambar 3 adalah perbandingan suhu drum, cerobong dan lingkungan. Dimana suhu drum lebih tinggi dibandingkan suhu cerobong dan suhu lingkungan, suhu drum yaitu pada awal pembakaran dihasilkan suhu yang sangat tinggi kemudian suhu tersebut cenderung menurun akibat biomassa pembakaran semakin berkurang atau habis, sedangkan cerobong sebagai sirkulasi udara sehingga terjadi pertukaran udara dari dalam alat pengering ke lingkungan hal ini menyebabkan suhu dicerobong cenderung lebih rendah dibandingkan suhu di dalam drum.

\section{Laju Panas Total yang Hilang pada Alat Pengering}

Gambar 4 menunjukkan bahwa nilai maksimum laju panas yang hilang berada pada menit ke 20 dikarenakan panas yang dihasilkan dari biomassa terbakar sempurna sehingga menghasilkan laju panas yang maksimal.

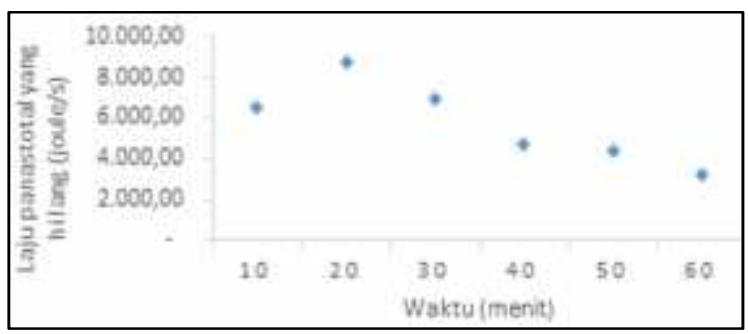

Gambar 4. Hubungan antara laju panas total yang hilang pada alat pengering terhadap waktu.

\section{Analisa kadar air yang hilang dari pakaian basah}

Hasil data pengamatan kadar air yang hilang dari pakaian basah dengan menggunakan 
persamaan. Gambar 5 memperlihatkan bahwa kadar air dari pakaian basah menurun seiring dengan bertambahnya waktu. Penurunan kadar air yang sangat drastis terjadi pada menit ke 10, dikarenakan panas yang dihasilkan di dalam alat pengering sangat tinggi.

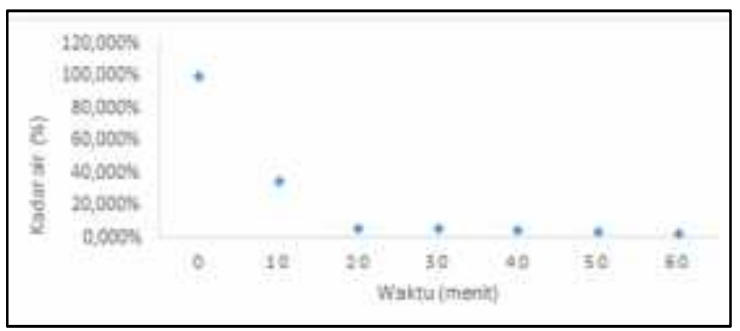

Gambar 5. Hubungan kadar air pakaian basa terhadap waktu

\section{Efesiensi Waktu Pengeringan}

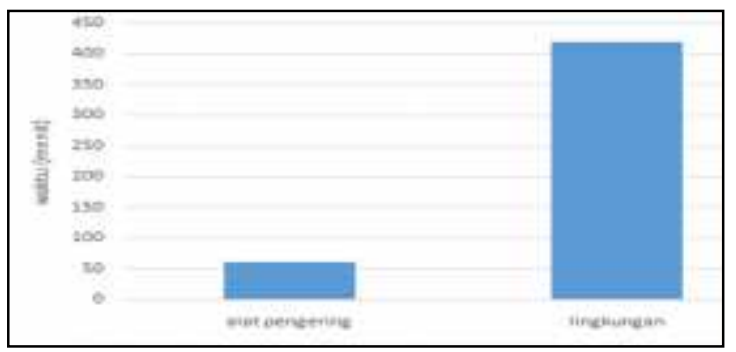

Gambar 6. Hubungan efisensi terhadap waktu pengeringan

Gambar 6 yang menunjukkan perbedaan efesiensi waktu pengeringan dengan menggunakan energi biomassa dan waktu pengeringan secara alami. Dimana untuk memperoleh tingkat kekeringan pakaian yang sama, pengiring biomassa hanya membutukan waktu 60 menit. Sementara pengeringan secara alami oleh lingkungan menghabiskan waktu 420 menit. Pengering biomassa menghemat waktu hingga $85.7 \%$ daripada pengering lingkungan (sinar matahari). Hal ini menunjukkan bahwa pengeringan dengan menggunakan energi biomassa lebih efektif dibandingkan menggunakan suhu lingkungan dan tidak bergantung pada kondisi cuaca, sehingga pada hari hujan pun malam hari pakaian basah masih bisa di keringkan, dan pengeringannya juga tidak memakan waktu yang lama.

\section{Laju Energi Biomassa Tempurung Kelapa}

Data perhitungan laju energi biomassa tempurung kelapa selama 60 menit dapat dilihat pada gambar 7. Massa yang dipakai untuk pembakaran adalah $4 \mathrm{~kg}$ dan dibagi di setiap drum nya $2 \mathrm{~kg}$ dengan waktu selama 60 menit. Laju energi biomassa terus turun dan sumber energi biomassa cenderung berkurang, hal ini disebabkan karena laju udara yang masuk cukup besar dan pembakaran limbah biomassa yang mulai habis.

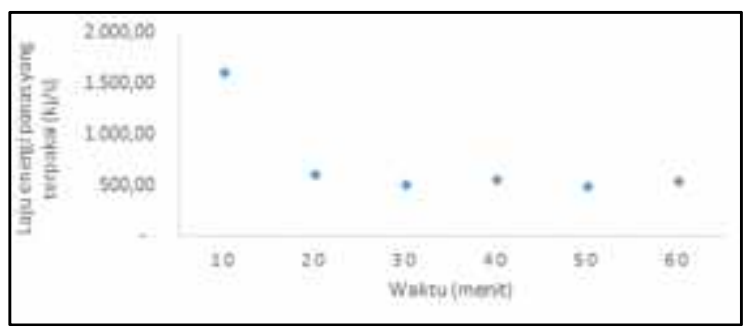

Gambar 7. Grafik hubungan antara laju panas energy biomassa tempurung terhadap waktu

\section{KESIMPULAN}

Berdasarkan hasil penelitian dan analisis dapat disimpulkan bahwa suhu didalam ruang alat pengering selalu lebih tinggi daripada suhu lingkungan. Laju total energi panas yang hilang pada alat pada menit ke 10 sebesar $6.527,54 \mathrm{~J} / \mathrm{s}$ dan terus berkurang hingga menit ke 60 sebesar $3.263,77 \mathrm{~J} / \mathrm{s}$. Laju energi panas yang dihasilkan dari pembakaran tempurung kelapa pada menit ke 10 sebesar 10520,0 J/menit dan terus berkurang hingga menit ke 60 sebesar 1753,3 $\mathrm{J} /$ menit. Efisiensi waktu pengeringan dengan menggunakan alat pengering energi biomassa mencapai $85,7 \%$.

\section{DAFTAR PUSTAKA}

1. Vachlepi, A. \& Suwardin, D. (2014). Pengeringan Karet Remah Berbasis Sumber Energi Biomassa. Warta Perkaretan, 33(2): 103-112.

2. Pangabean, T., Triana, A. N., \& Hayati, A. (2014). Rancangan Alat Pengering Rengginang Hybrid Energi Surya dan 
Biomassa Pelepah Kelapa Sawit. Prosiding Seminar Nasional FTI UNPAD-PERTETAHIPI 2014: Buku II-Alat dan Mesin Pertanian. Jatinangor, 11-12 November 2014. hlm. 79-86.

3. Yahya, M. (2015). Kajian Karakteristik Pengering Fluidisasi Terintegrasi dengan Tungku Biomassa untuk Pengeringan Padi. Jurnal Teknik Mesin, 5(2), 65-71.

4. Jading, A., Tethool, E., Payung, P., \& Gultom, S. (2011). Karakteristik Fisikokimia Pati Sagu Hasil Pengeringan secara Fluidisasi Menggunakan Alat Pengering Cross Flow Fluidized Bed Bertenaga Surya dan Biomassa. Reaktor, 13(3) , 155-164.

5. Juandi, M., Eka A., E., \& Salomo. (2015). Pemanfaatan Limbah Tempurung Kelapa sebagai Energi Biomassa untuk Pengeringan Hasil Pertanian. Komunikasi Fisika Indonesia. 15(10), 644- 650.

6. Syamsiro, M. \& Saptoadi, H. (2007). Pembakaran Briket Biomassa Cangkang Kakao: Pengaruh Temperatur Udara Preheat. Seminar Nasional Teknologi 2007 (SNT 20), Yogyakarta, 24 November 2007. hlm. B-1B-10.
7. Jamilatun, S. (2008). Sifat-Sifat Penyalaan dan Pembakaran Briket Biomassa, Briket Batubara dan Arang Kayu. Jurnal Rekayasa Proses, 2(2), 37-40.

8. Purwadi, P. K. \& Kusbandono, W. (2016). Peningkatan Waktu Pengeringan Dan Laju Pengeringan Pada Mesin Pengering Pakaian Energi Listrik. Prosiding Seminar Nasional ReTII ke-11 2016, 432-437.

9. Juandi, M. \& Panca, O. (2017). Efek Variasi Massa Dari Biomassa Limbah Tempurung Kelapa Terhadap Laju Penurunan Kadar Air Sebagai Fungsi Waktu Hasil Pengeringan Buah Pinang Dengan Alat Pengering Tipe Kabinet. Jurnal APTEK, 9(1), 46-51.

10. Riyanto, A. A. \& Liunir, L. (2009). Dasar Busana. Modul Ajar. Program Studi Pendidikan Tata Busana Jurusan Pendidikan Kesejahteraan Keluarga Fakultas Pendidikan Teknologi Dan Kejuruan, Universitas Pendidikan Indonesia, Bandung Indonesia.

11. Juandi, M. \& Haekal, M. R. (2016). Karakterisasi Pengaruh Suhu Terhadap Parameter Fisis Biji Pinang Hasil Pengeringan Menggunakan Alat Tipe Kabinet Dengan Limbah Tempurung Kelapa Sebagai Sumber Panas. Junal Ilmu Fisika, 8(1), 38-44. 